\title{
IMPLEMENTASI DAN PERMASALAHAN DALAM IMPLEMENTASI PERMENDIKNAS NOMOR 2 TAHUN 2008 TENTANG BUKU
}

\author{
Lina Miftahul Jannah, Muh. Azis Muslim, Eko Sakapurnama \\ Universitas Indonesia \\ miftahul@ui.ac.id; muhazis@ui.ac.id; eko.sakapurnama@ui.ac.id
}

\begin{abstract}
Abstrak
Penelitian ini bertujuan untuk mengetahui implementasi Permendiknas Nomor 2 Tahun 2002 tantang buku dan mendeskripsikan masalah-masalah yang ditimbulkannya. Penelitian dilaksanakan dengan metode campuran kuantitatif dan kualitatif di Kota Depok, Kabupaten Cianjur, Kota Makassar, dan Kabupaten Maros dengan menggunakan angket, wawancara mendalam dan diskusi kelompok terfokus untuk mengumpulkan data. Hasil penelitian menunjukkan bahwa implementasi Permendiknas yang bertujuan untuk menyediakan buku murah dan berkualitas bagi masyarakat belum sepenuhnya tercapai. Terdapat beragam masalah dalam pelaksanaannya antara lain minimnya sosialisasi, tidak memadainya infrastruktur teknologi informasi, ketidaksesuaian materi dengan kurikulum, rendahnya kualitas cetakan, dan Permendiknas dianggap sebagai kebijakan elitis yang mematikan iklim persaingan usaha.
\end{abstract}

Kata kunci: kebijakan, pelaksanaan, buku cetak, buku sekolab elektronik 
Jurnal Penelitian dan Evaluasi Pendidikan

\title{
IMPLEMENTATION AND ISSUES IN IMPLEMENTATION PERMENDIKNAS NUMBER 2 OF 2008 ON THE BOOK
}

\author{
Lina Miftabul Jannah, Muh. Aqis Muslim, Eko Sakapurnama \\ Universitas Indonesia \\ miftahul@ui.ac.id; muhazis@ui.ac.id; eko.sakapurnama@ui.ac.id
}

\begin{abstract}
This research aims to figure out and elaborate the implementation of Cultural and Educational Ministry's regulation No 2, 2002 as well as the problems occurring during the implementation. The research was conducted by applying mixed method -qualitative and quantitative- held in Depok City, Cianjur Regency, Makassar City, and Maros Regency using questionnaires, interviews and focus group discussion to collect data. The result shows that the implementation of regulation, which originally aimed to provide affordable and quality book for the people, fails to achieve its purpose. There are various problems found in the implementation, e.g. lack of socialization, lack of information technology infrastructure, unfitness between the materials with the curriculum, lack of printing quality, and the prevailing opinion that the regulation is an elitist policy that kills business competition.
\end{abstract}

Keywords: implementation, policy, education, text book 


\section{Pendahuluan}

Perkembangan dan kemajuan suatu bangsa sangat dipengaruhi oleh pendidikan. Melalui pendidikan diharapkan dapat menciptakan sumber daya manusia yang berkualitas sehingga mampu menghadapi perubahan yang terjadi dalam masyarakat. Dalam Pembukaan Undang-Undang Dasar 1945 juga ditegaskan bahwa salah satu tujuan negara Indonesia adalah mencerdaskan kehidupan bangsa dan juga disebutkan bahwa pendidikan merupakan tanggung jawab negara.

Sejalan dengan sistem pemerintahan Indonesia yang mengalami perubahan pasca Undang-Undang Nomor 22 Tahun 1999 tentang Pemerintahan Daerah yang kemudian direvisi kedalam Undang-Undang Nomor 32 Tahun 2004 dari sentralisasi menjadi desentralisasi, mengakibatkan perubahan pula dalam pembagian kewenangan, termasuk dalam bidang pendidikan. Pemerintah pusat selain mengelola Pendidikan Tinggi juga membuat kebijakan nasional, sedangkan Pemerintah Daerah (Kabupaten/Kota) berwenang mengelola Pendidikan Dasar dan Menengah. Pemerintah, baik pusat maupun daerah, wajib memberikan layanan dan kemudahan, serta menjamin terselenggaranya pendidikan yang bermutu bagi setiap warga negara tanpa diskriminasi. Pemerintah harus menyediakan segala kebutuhan pendidikan, baik kurikulum, sarana dan prasarana, guru, dan buku pelajaran. Terkait dengan buku pelajaran atau yang dikenal dengan istilah buku teks, penyediaannya ternyata mengalami banyak masalah, mulai dari keluhan orangtua siswa mengenai tingginya harga buku teks pelajaran, kurangnya persediaan buku, kecenderungan pemakaian buku teks yang telah ditentukan sebelumnya, juga keluhan mengenai penerbit yang cenderung mengambil posisi dominan dalam pengadaan buku

Sejak 2005, pemerintah juga telah mengatur tentang buku teks pelajaran melalui Peraturan Menteri Pendidikan Nasional (Permendiknas) Nomor 11 Tahun 2005. Pemerintah juga telah mengeluarkan program Bantuan Operasional Sekolah Buku. Kebijakan ini semakin dipertegas dalam Permendiknas Nomor 2 Tahun 2008 tentang Buku. Permendiknas ini mengatur bagaimana buku harus dibuat, bagaimana buku ini dapat

Implementasi dan Permasalahan dalam Implenentasi PERMENDIKNAS - 309

Lina Mifathul Jannah, Muh. Aziz Muslim, Eko Sukapurnama 
diedarkan, siapa yang dapat menjual, dan berapa buku ini harus dijual. Langkah yang telah dilakukan pemerintah adalah membeli hak cipta buku pelajaran dari penulis.

Kebijakan ini mempermudah distribusi buku dan mempermurah biaya mendapatkan buku. Salah satunya melalui jaringan internet dalam bentuk PDF (e-book) sehingga masyarakat (siswa, guru, orangtua, dan siapapun) dapat mengaksesnya secara langsung. Dalam kenyataannya, masih banyak guru, orangtua, dan tentu juga siswa yang belum dapat merasakan manfaat dari program Buku Sekolah Elektronik (BSE) ini karena terbentur beberapa masalah, seperti terbatasnya ketersediaan perangkat komputer, belum adanya fasilitas jaringan internet untuk dapat mengunduh BSE secara online, dan masih banyak kendala-kendala lainnya sehingga sulit untuk memanfaatkan program ini secara maksimal. Untuk itu menarik untuk mengetahui bagaimana implementasi Permendiknas Nomor 2 Tahun 2008 tentang Buku dan masalah-masalah apa yang terjadi dalam implementasi Permendiknas Nomor 2 Tahun 2008 tentang Buku.

Hipotesis yang diajukan dalam penelitian ini adalah Permendiknas Nomor 2 Tahun 2008 belum terlaksana dengan baik dan mengalami permasalahan dalam implementasinya. Penelitian dilaksanakan dengan mixed method kuantitatif dan kualitatif. Dengan menggunakan metode campuran ini, diharapkan peneliti dapat memperoleh gambaran menyeluruh tentang implementasi dan masalah-masalah dalam implementasi Permendiknas Nomor 2 Tahun 2008 tentang Buku. Metode kuantitatif yang digunakan adalah survei (melalui penyebaran kuesioner untuk siswa Sekolah Menengah Atas/SMA). Jumlah responden di wilayah kota Makassar, Kabupaten Maros, dan Kabupaten Cianjur masing-masing sebanyak 25 responden, sedangkan untuk Kota Depok sebanyak 27 reseponden. Total responden pada penelitian ini adalah 102 responden. Pemilihan siswa sebagai responden dari setiap wilayah dilakukan secara accidental sampling. Terkait dengan metode kualitatif, teknik pengumpulan data yang digunakan adalah wawancara mendalam kepada sekolah yang diwakili oleh kepala sekolah, lembaga swadaya masyarakat yang bergerak di bidang pendidikan, dan Badan Standar Nasional Pendidikan (BSNP), dan 
Dinas Pendidikan. dan diskusi kelompok terarah dilakukan kepada guru, orangtua, dan penerbit/pedagang buku.

Penelitian ini mengambil lokasi di Provinsi Jawa Barat yaitu Kota Depok dan Kabupaten Cianjur, dan Provinsi Sulawesi Selatan yaitu Kota Makassar, Kabupaten Maros. Asumsi pemilihan lokasi kota yaitu mengindikasikan tingkat penggunaan internet yang tinggi dan kualitas pendidikan lebih baik, sedangkan kabupaten mengindikasikan tingkat penggunaan internet yang rendah, kualitas pendidikan lebih rendah.

Ada dua teori utama yang digunakan dalam penelitian ini, yaitu impelementasi kebijakan dan buku teks. Implementasi kebijakan merupakan proses atau tahapan yang penting dalam sebuah tahapan kebijakan. Bagaimanapun, sebuah kebijakan yang telah dihasilkan apabila tidak dilaksanakan maka akan sia-sia atau tidak dapat mengatasi suatu permasalahan. Implementasi juga penting karena menentukan berhasil atau tidaknya suatu kebijakan dibuat guna memecahkan suatu masalah. Crabbé and Leroy (2008, p.15) menjelaskan bahwa implementasi kebijakan merupakan sebuah proses di mana berbagai keputusan perlu untuk terusmenerus dibuat, dan seluruh kekuasaan, penerimaan, informasi, kapasitas dan elemen lain memainkan sebuah peranan yang penting. Sementara itu O’Toole (2000) mendefinisikan implementasi kebijakan sebagai apa yang berkembang antara pembentukan sebuah maksud yang jelas pada bagian pemerintah untuk melakukan sesuatu, atau untuk berhenti melakukan sesuatu, dan dampak akhir dalam serangkaian tindakan.

Lester dan Stewart (1996 : 97-98) menyatakan bahwa implementasi kebijakan dapat dilihat dari proses, output, dan outcomes. Dalam hal proses, implementasi merupakan serangkaian keputusan dan tindakan yang diarahkan agar peraturan yang ada dapat menghasilkan suatu efek. Dalam hal output, implementasi dapat dipahami sebagai sejauh mana tujuan suatu program didukung, seperti tingkatan pengeluaran yang dikomitmenkan untuk sebuah program atau jumlah pelanggaran yang diterbitkan agar ada kepatuhan terhadap petunjuk pelaksanaan suatu progam. Dalam hal outcomes, dapat dipahami bahwa hasil implementasi menyiratkan bahwa telah ada beberapa perubahan yang terukur pada masalah yang lebih besar yang telah ditangani oleh program tersebut, hukum publik, atau keputusan 
pengadilan. Definisi van Meter dan van Horn (Lester, J. P and Stewart, J, JR. 2000). Memperlihatkan bahwa implementasi kebijakan merupakan tindakan dari aktor pemerintah atau swasta yang diarahkan pada pencapaian suatu tujuan tertentu. Dengan demikian, implementasi lebih melihat pada tindakan daripada melihat dampak dari kebijakan tersebut.

Dalam proses implementasi atau pelaksanaan kebijakan, kemungkinan akan selalu terbuka terjadinya perbedaan antara apa yang diharapkan atau yang sudah direncanakan oleh para pembuat kebijakan dengan apa yang senyatanya dicapai (sebagai hasil atau prestasi dari pelaksanaan kebijakan tadi). Hal inilah yang kemudian disebut dengan implementation gap atau kesenjangan. Pada batas tertentu kesenjangan ini masih dapat dibiarkan, sekalipun dalam monitoring harus diidentifikasi untuk segera diperbaiki apalagi jika kesenjangan yang terjadi lebih besar dari batas toleransi maka harus segera diperbaiki.

Implementation gap dapat terjadi antara lain karena, pertama tidak melaksanakan atau dilaksanakan tidak sebagaimana mestinya (non implementation). Kedua, karena tidak berhasil atau mengalami kegagalan dalam proses (unsuccesful implementation). Ketiga, pelaksanaan dilakukan sesuai dengan ketentuan yang ada, tetapi dalam prosesnya terjadi hambatan yang tidak dapat diatasi.

Terdapat beraga jenis buku yang biasa digunakan di sekolah. Salah satunya adalah buku teks. Buku teks menurut A.J. Loveridge merupakan buku sekolah yang memuat bahan yang telah diseleksi mengenai bidang studi tertentu, dalam bentuk tertulis yang memenuhi syarat tertentu dalam kegiatan belajar mengajar, disusun secara sistematis untuk diasimilasikan. Chambliss dan Calfee (1998) juga menjelaskannya bahwa buku teks merupakan alat bantu siswa untuk memahami dan belajar dari hal-hal yang dibaca dan untuk memahami dunia (di luar dirinya).

Dalam Permendiknas Nomor 2 Tahun 2008 tentang Buku disebutkan bahwa buku teks adalah buku acuan wajib untuk digunakan di satuan pendidikan dasar dan menengah atau perguruan tinggi yang memuat materi pembelajaran dalam rangka peningkatan keimanan, ketakwaan, akhlak mulia, dan kepribadian, penguasaan ilmu pengetahuan dan teknologi, peningkatan kepekaan dan kemampuan estetis, peningkatan 
kemampuan kinestetis dan kesehatan yang disusun berdasarkan standar nasional pendidikan. Buku teks berguna bukan hanya bagi guru dan siswa tetapi juga bagi orang tua. Bagi guru dan siswa buku teks berguna sebagai acuan wajib karena dapat digunakan sebagai pedoman materi pembelajaran.

\section{Hasil Penelitian dan Pembahasan}

Hasil penelitian menunjukkan bahwa Permendiknas Nomor 2 Tahun 2008 sudah dilaksanakan, namun demikian belum berjalan dengan baik di semua pemangku kepentingan. Pasal 6 dan 7 Permendiknas tentang Buku telah menyebutkan bahwa buku teks sebagai acuan wajib oleh pendidik dan peserta didik dalam proses pembelajaran. Pendidik dapat menggunakan buku panduan pendidik, buku pengayaan, dan buku referensi dalam proses pembelajaran. Pendidik dapat menganjurkan kepada peserta didik yang mampu untuk memiliki buku. Anjuran tersebut seharunya bersifat tidak memaksa atau tidak mewajibkan. Dalam kenyataannya, peneliti menemukan bahwa di Kabupaten Maros, sebagian besar responden menyatakan bahwa guru mewajibkan siswa memiliki buku teks.

Di wilayah Kota Makasar, Kabupaten Cianjur, dan Kota Depok, responden tidak terlalu mengalami kesulitan untuk memperoleh buku teks, namun tidak demikian di Kabupaten Maros. Penyediaan buku diatur dalam Pada Pasal 7 ayat (4) Permendiknas tentang Buku menyebutkan "Satuan pendidikan wajib menyediakan buku teks di perpustakaan dan pendidik menganjurkan kepada semua peserta didik untuk meminjam buku teks pelajaran di perpustakaan satuan pendidikan atau memilikinya." Sebagian besar responden menyatakan bahwa mereka memperoleh buku teks dengan cara membeli dari koperasi sekolah $(38,2 \%)$, membeli di toko buku, baik toko buku besar maupun toko buku kecil (24,5\%), dan meminjam di perpustakaan (12,7\%). Sisanya memperoleh buku teks dengan meminjam kepada kerabat atau teman, membeli pada guru, membeli di toko loak, dan menggandakan sendiri. 


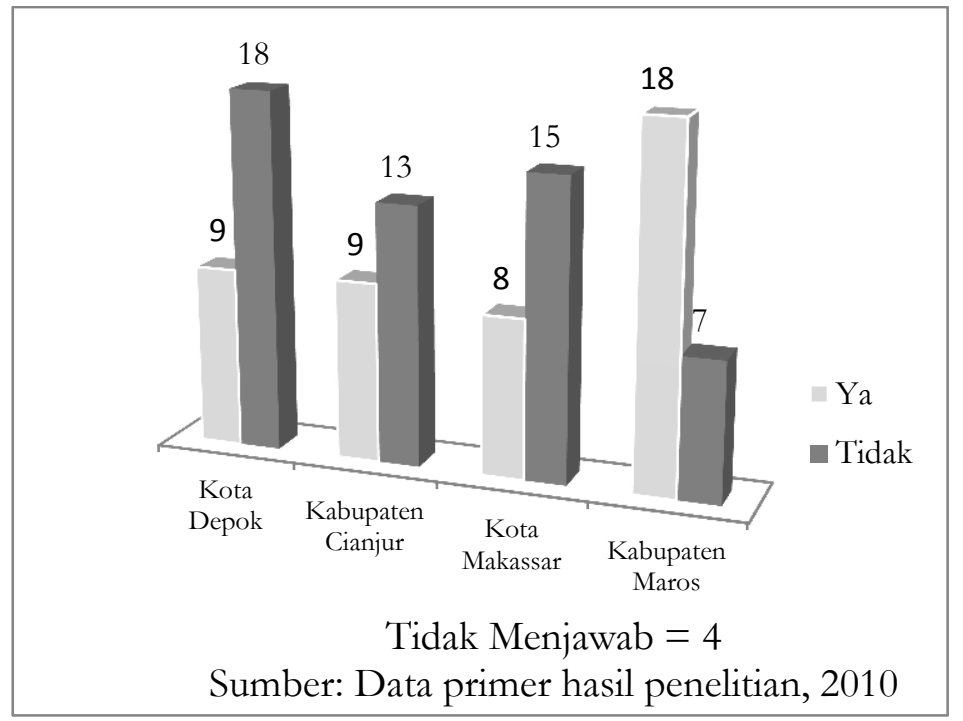

Gambar 1. Grafik Guru Mewajibkan Memiliki Buku Teks Berdasarkan Wilayah

Terkait dengan kebijakan ini, Pasal 11 Permendiknas ini menyebutkan bahwa pendidik, tenaga kependidikan, anggota komite sekolah/madrasah, dinas pendidikan pemerintah daerah, pegawai dinas pendidikan pemerintah daerah, dan/atau koperasiyang beranggotakan pendidik dan/atau tenaga kependidikan satuan pendidikan, baik secara langsung maupun bekerjasama dengan pihak lain, dilarang bertindak menjadi distributor atau pengecer buku kepada peserta didik di satuan pendidikan yang bersangkutan atau kepada satuan pendidikan yang bersangkutan, kecuali untuk buku-buku yang hak ciptanya sudah dibeli oleh Departemen, departemen yang menangani urusan agama, dan/atau Pemerintah daerah sebagaimana dimaksud dalam Pasal 3 ayat (4) dan dinyatakan dapat diperdagangkan sebagaimana dimaksud dalam Pasal 8 ayat (1). Kondisi ini jelas melanggar ketentuan, karena guru atau koperasi di sekolah ternyata menjual buku teks di luar yang dibeli hak ciptanya oleh pemerintah. Alasan yang diberikan, baik oleh koperasi dan guru, adalah 
untuk mempermudah siswa daripada harus mencari ke toko buku, terutama di Kabupaten Maros dan Cianjur. Padahal dari hasil wawancara dengan penerbit, didapatkan informasi bahwa guru memperoleh komisi dari buku teks yang dijualnya antara 30-40\%. Menurut para guru, komisi ini tidak diterimanya semua karena dibagi juga dengan kepala sekolah dan komite sekolah.

Kebijakan BSE sudah dikeluarkan sejak tahun 2008. Sesuatu yang mencengangkan jika melihat bahwa lebih dari 2 tahun, masih ada pihak yang terkait dengan pendidikan, dalam hal ini siswa, tidak mengetahui tentang BSE. Ternyata, bukan hanya siswa saja yang tidak tahu. Diakui oleh beberapa guru di Depok, bahwa mereka sendiri tidak tahu tentang BSE. Menurut mereka, tidak pernah ada sosialisasi dari dinas pendidikan. Informasi ini ditentang oleh Dinas Pendidikan yang menyatakan sudah menyampaikan informasi kepada kepala sekolah.

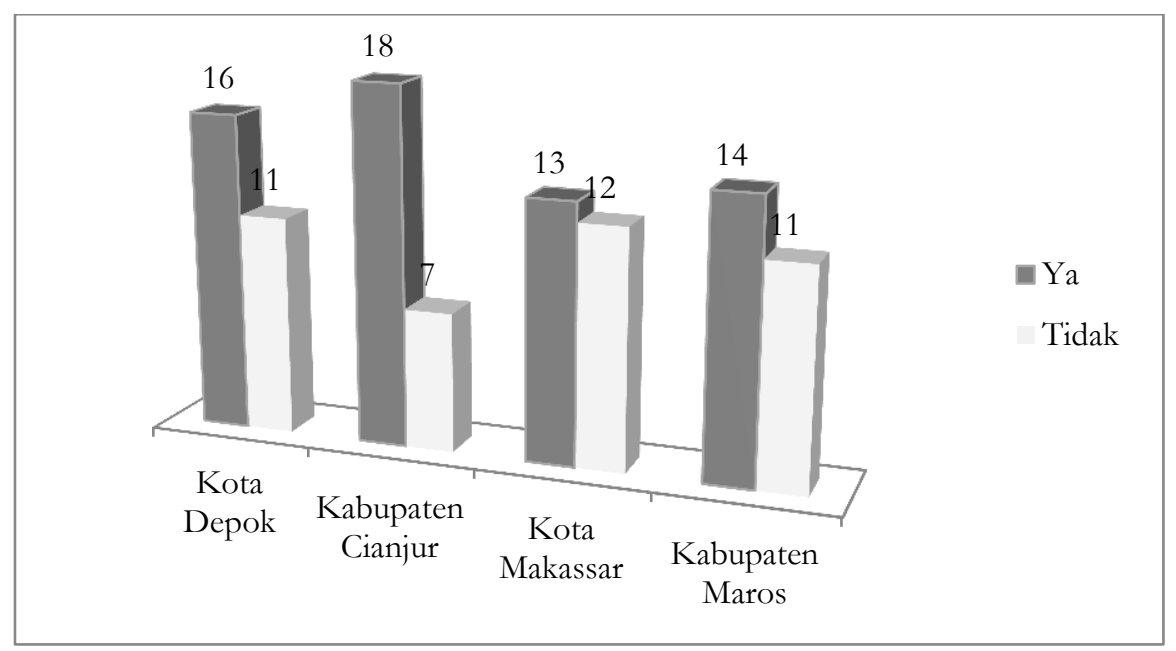

Gambar 2. Pengetahuan Responden tentang Buku Sekolah Elektronik Berdasarkan Wilayah 
Pendapat resonden tentang BSE berdasarkan wilayah disajikan pada gambar 2. Berdasarkan hasil tersebut, diperoleh bahwa responden memperoleh informasi tentang BSE lebih lebih banyak melalui media cetak dan media internet. Internet yang diharapkan dapat juga memberikan informasi memiliki kendala dalam jangkauan terutama di wilayah yang terpencil.

Berdasarkan situs www.bse.kemdiknas.go.id diperoleh data bahwa hingga saat terdapat 958 judul BSE Buku-buku ini telah dinilai kelayakan pakainya oleh Badan Standar Nasional Pendidikan (BSNP) dan telah ditetapkan sebagai buku teks pelajaran yang memenuhi syarat kelayakan untuk digunakan dalam pembelajaran melalui Peraturan Menteri Pendidikan Nasional (Permendiknas) Nomor 46 Tahun 2007, Nomor 22 Tahun 2007, Nomor 27 Tahun 2007, Nomor 12 Tahun 2008, Nomor 34 Tahun 2008, Nomor 41 Tahun 2008, Nomor 69 Tahun 2008, Nomor 80 Tahun 2008, Nomor 81 Tahun 2008, dan Nomor 9 Tahun 2009. Untuk tingkat SD, buku teks mata pelajaran yang dibeli hak ciptanya oleh pemerintah adalah Bahasa Indonesia, Matematika, IPA, IPS, dan PKn (Pendidikan Kewarganegaraan), sedangkan untuk tingkat SMP yaitu Bahasa Indonesia, Bahasa Inggris, Matematika, IPA, IPS, dan PKn.

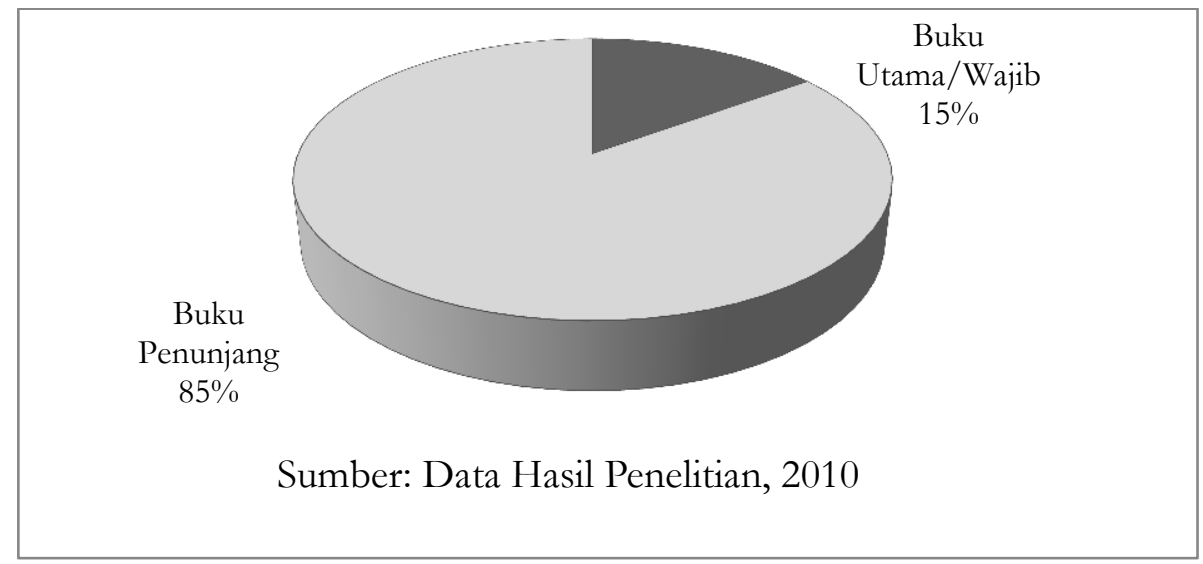

Gambar 3. Grafik Kegunaan Buku Sekolah Elektronik 
Informasi yang diperoleh dari guru menunjukkan bahwa biasanya BSE memang hanya dipakai sebagai buku penunjang saja, karena biasanya lebih tidak menarik dan tidak lengkap dibandingkan dengan buku yang diterbitkan oleh penerbit. Diakui oleh penerbit, mungkin karena harus melalui internet dengan kapasitas terbatas, BSE dibuat lebih sederhana.

Tabel 1. Penilaian Responden tentang Buku Cetak Biasa dan Buku Sekolah Elektronik

\begin{tabular}{|l|l|l|}
\hline \multicolumn{1}{|c|}{ Indikator } & \multicolumn{1}{|c|}{ Buku Cetak Biasa } & \multicolumn{1}{c|}{ Buku Sekolah Elektronik } \\
\hline Harga & Mahal $(62,1 \%)$ & Murah $(48,9 \%)$ \\
\hline Kualitas kertas & Bagus $(54,9 \%)$ & Bagus $(52,1 \%)$ \\
\hline Kualitas cetakan & Baik $(71,0 \%)$ & Baik $(58,7 \%)$ \\
\hline Isi materi & Lengkap $(39,6 \%)$ & Lengkap $(51,1 \%)$ \\
\hline Penjelasan materi & Jelas $(47,9 \%)$ & Jelas $(55,3 \%)$ \\
\hline Warna & Menarik $(42,7 \%)$ & Menarik $(51,1 \%)$ \\
\hline
\end{tabular}

Walaupun hasil penelitian menunjukkan tidak ada perbedaan yang terlalu berarti antara BSE dengan buku cetak biasa, namun hasil pengujian statistik menunjukkan kebalikannya. Nilai signifikansi adalah 0,000. Jika dibandingkan dengan nilai alpha 0,05, maka nilai signifikansi berarti lebih besar dibandingkan dengan nilai alpha. Iniberarti bahwa ada perbedaan penilaian yang signifikan antara buku cetak biasa dengan BSE.

Ini terbukti dari jawaban responden ketika ditanyakan mana yang lebih dipilih oleh responden antara buku cetak biasa dengan buku sekolah elektronik, mayoritas responden, yakni sebanyak $61,86 \%$, lebih memilih buku cetak biasa dibandingkan buku sekolah elektronik.

Ada beberapa masalah terkait dengan pelaksanakan Permendiknas tentang Buku ini. Pertama, minimnya sosialisasi program BSE. Salah satu masalah utama yang dihadapi adalah minimnya informasi yang diterima berbagai pihak terkait penyelenggaraan BSE.

Implementasi dan Permasalahan dalam Implenentasi PERMENDIKNAS - 317

Lina Mifathul Jannah, Muh. Aziz Muslim, Eko Sukapurnama 
"Tidak pernah ada sosialisasi tentang BSE. Dengar sudah pernah...ngapain BSE, sementara buku tersebut tidak ada di BSE” (FGD Depok)

Tabel 2. Hasil Pengujian Statistik menggunakan Uji Perbedaan Wilcoxon

\begin{tabular}{|c|c|c|c|c|}
\hline & & $\mathrm{N}$ & $\begin{array}{l}\text { Mean } \\
\text { Rank }\end{array}$ & $\begin{array}{c}\text { Sum of } \\
\text { Ranks }\end{array}$ \\
\hline \multirow{4}{*}{$\begin{array}{l}\text { BSE - } \\
\text { BUKU } \\
\text { CETAK }\end{array}$} & $\begin{array}{l}\text { Negative } \\
\text { Ranks }\end{array}$ & $8(a)$ & 14,50 & 116,00 \\
\hline & $\begin{array}{l}\text { Positive } \\
\text { Ranks }\end{array}$ & $29(b)$ & 20,24 & 587,00 \\
\hline & Ties & $7(\mathrm{c})$ & & \\
\hline & Total & 44 & & \\
\hline
\end{tabular}

\begin{tabular}{|c|c|}
\hline & $\begin{array}{l}\text { BSE - } \\
\text { BUKU } \\
\text { CETAK }\end{array}$ \\
\hline$Z$ & $-3,586$ \\
\hline $\begin{array}{l}\text { Asymp. } \\
\text { Sig. (2- } \\
\text { tailed) }\end{array}$ & 0,000 \\
\hline
\end{tabular}

Masalah informasi ini bukan hanya pada saat buku telah selesai, tetapi juga saat penyeleksian dan penilaian buku yang diajukan. Tidak jelas kapan waktunya. Sebenarnya, terkait dengan informasi yang tidak jelas ini, dari situs http://bsnp-indonesia.org dapat ditemukan informasi yang lengkap tentang instrumen penilaian buku teks dan juga pengumuman penilaian buku teks pelajaran. Jadi, mungkin informasi ini yang tidak diakses atau diterima oleh para penulis buku.

Masalah kedua yaitu infrastruktur teknologi informasi tidak memadai. Tidak setiap siswa dan sekolah memiliki jaringan internet.

"Kalaupun ada jaringan internet sekolah harus bayar sendiri. Biasanya kerjasama dengan telkom. (FGD Makassar, Maros, dan Cianjur)"

BSE yang diharapkan lebih murah karena dapat diakses di mana saja, malah menjadi mahal karena akses yang lambat dan belum tersedianya perangkat di sekolah. Di Depok saja, ketika peneliti mencoba mencari toko buku yang menjual BSE, jumlahnya sangat sedikit. Mata harus jeli melihat 
di sepanjang jalan yang memang memasang pengumuman menjual BSE. Pemerintah sebenarnya dapat memfasilitasi BSE tidak seperti model cetak seperti saat ini. Penggunaan cakram padat atau cakram digital menjadi salah satu pilihan. Biaya penggantian dua keping cakram digital berisi total 800an judul buku hanya dikenai biaya Rp 95.000,-(sudah termasuk ongkos kirim kemana saja di Indonesia dengan Pos Khusus). Tapi, tentu saja. untuk menggunakan cakram digital ini diperlukan perangkat pemutar, dan itu berarti biaya. Bagi yang memiliki komputer atau laptop dengan pemutar cakram, mungkin menjadi suatu pilihan lebih murah.

Masalah ketiga adalah ketidaksesuaian materi dengan kurikulum yang berlaku. BSNP adalah lembaga yang salah satu kewenangannya untuk menilai kelayakan isi, bahasa, penyajian, dan kegrafikaan buku teks pelajaran. Buku-buku yang dibeli hak ciptanya oleh pemerintah harus melalui tahap penilaian oleh lembaga ini. Dengan melalui uji kelayakan ini, seharusnya materi yang ada di buku teks atau BSE dapat dipastikan sesuai dengan kurikulum yang berlaku.

Namun demikian, tidak semuanya setuju dengan pernyataan bahwa kualitas BSE sama dengan buku cetak lain yang dikeluarkan oleh penerbit besar.

"Materi muatan lokalnya kurang. Jadi kurang lengkap dibandingkan dengan buku cetak." (FGD Maros)

Masalah keempat dalam pelaksanaan Permendiknas Nomor 2 Tahun 2008 adalah ada indikasi kerjasama guru/sekolah dengan penerbit dalam menjual buku cetak. Memang tidak ada bukti bahwa guru atau sekolah melakukan kerjasama dalam menjual buku cetak. Namun, dari hasil FGD diperoleh informasi bahwa ada komisi yang diberikan penerbit kepada sekolah atau guru atas buku-buku yang dijual yang nilai besaran komisi minimal 10\% dan bisa mencapai hingga 30 sampai 40 persen. Jadi penerbit biasanya akan mendatangi sekolah atau guru untuk menawarkan buku terbitannya.

"Sejak ada kebijakan BSE itu malah penerbit semakin massif." (Wawancara dengan LSM) 
Distribusi tidak merata menjadi masalah kelima. Penetapan harga eceran tertinggi (HET) oleh pemerintah terhadap BSE versi cetak yang dinilai terlalu rendah, banyak pengganda enggan mendistribusikan ke daerah terpencil karena biaya operasional tidak sesuai dengan margin karena HET terlalu rendah. Informasi yang diperoleh dari IKAPI Jakarta menyebutkan bahwa harga kertas di Aceh jauh lebih mahal dibandingkan dengan Jakarta atau di Pulau Jawa. Jadi, kalau siswa, orang tua, atau guru mau mencetak sendiri, biayanya lebih mahal dibandingkan dengan membeli buku di toko buku. Di Depok, misalnya, kertas ukuran A4 70 gram setiap rimnya hanya sekitar Rp. 25.000,00 saja, tetapi di wilayah lain bisa mencapai Rp. 35.000,00.

Kualitas cetakan rendah menjadi masalah yang keenam. Menurut Pedagang BSE di Depok, satu buku dihargai minimal Rp. 10.000,00, sedangkan menurut penerbit di Cianjur harga BSE di bawah 25.000,00. Harga ini memang di bawah harga buku-buku terbitan penerbit ternama yang mencapai Rp. 40.000,00. Bahkan akibat HET yang telah ditetapkan ini, kualitas buku menjadi rendah. Menurut siswa yang diwawancara, terbukti dengan ditemukannya buku-buku yang cetakannya tidak jelas terbaca. Selain itu, banyak buku BSE yang dicetak dengan kertas yang tidak sesuai dengan ketentuan. Menurut pedagang buku di Depok, hal ini harus dilakukan untuk menekan biaya produksi.

Ketujuh, Permendiknas ini juga dianggap mematikan iklim persaingan usaha. Sejak diberlakukan BSE, Pemutusan Hubungan Kerja besar-besaran di industri penerbitan tidak dapat dihindari. Banyak karyawan penerbitan yang harus kehilangan pekerjaan karena pekerjaan mereka telah digantikan oleh peran pemerintah. Sebelum Permendiknas 2008 dikeluarkan, penerbit besar membuka kantor cabang di beberapa kota besar di Indonesia. Setelah 2008, beberapa penerbit menutup kantornya ini, seperti yang terjadi di Kabupaten Cianjur.

Masalah kedelapan terkait dengan kualitas sumber daya manusia pendidik dan siswa yang belum merata. Tidak semua wilayah memiliki sumber daya pendidik dan siswa dengan kualitas yang sama. Di daerah perkotaan, melek informasi dan teknologi menjadi suatu hal yang lumrah. Menurut data Kementerian Komunikasi dan Informatika 
(Kominfo), jumlah pengguna internet dari komputer dan ponsel hingga Juni 2010 sudah mencapai 45 juta. Angka ini meningkat tajam jika dibandingkan dengan kondisi tahun 1999 yang hanya satu juta pengguna. Dalam kenyataannya internet hanya digunakan sekedar mengirim surat (mailing), mengobrol (chatting) melalui jejaring sosial, atau melihat (browsing). Responden dalam penelitian ini misalnya, sebagian besarnya menggunakan internet terkait dengan jaringan pertemanan. Selain telepon genggam, responden juga biasa menggunakan warnet untuk mengakses internet $(35,3 \%)$. Hanya $25,5 \%$ saja yang menggunakan komputer atau komputer jinjing pribadi untuk mengakses internet. Jarang sekali yang menyatakan menggunakan internet untuk kepentingan belajar. Kecepatan dan kemampuan para siswa dalam mengadopsi teknologi informasi tidak dapat diikuti oleh para pendidik. Jika para siswa adalah generasi native speaker technology maka sebagian besar guru lahir sebelum era 80-an, atau lebih dikenal generasi digital immigrant yang terkadang gagap teknologi. Terkait dengan penggunaan BSE, hasil penelitian di Cianjur menunjukkan bahwa hanya 25\% saja guru yang menggunakan BSE.

Terlambatnya distribusi BSE yang telah dicetak oleh pemerintah akibat keterlambatan pencairan anggaran menjadi masalah kesembilan. Untuk tingkat SD dan SMP, pada tahun 2010 dan sebelumnya, pemerintah menganggarkan pembelian buku melalui dana BOS Buku. BOS (Bantuan Operasional Sekolah) adalah program pemerintah untuk penyediaan pendanaan biaya operasi non personalia bagi satuan pendidikan dasar sebagai pelaksana program wajib belajar. Salah satu jenis BOS adalah BOS Buku yang hanya diperuntukkan bagi penyediaan buku yang dibutuhkan dalam proses belajar mengajar. Mulai Januari 2009, besaran BOS Buku per siswa per tahun untuk SD di kota dan di kabupaten masing-masing sebesar Rp. 400.000,00 dan Rp. 397.000,00, sedangkan untuk SMP di kota dan di kabupaten masing-masing sebesar Rp. 575.000,00 dan Rp. 570.000,00 Melalui BOS Buku, pihak sekolah mengajukan buku dan jumlah yang akan dibeli. Dengan catatan, buku yang dibeli harus yang tercatat dalam daftar buku yang memang telah diuji kelayakannya. Hanya saja, tidak semua buku cetak yang dibutuhkan dapat dibeli setiap tahunnya. Misalnya tahun ajaran 2008 hanya bisa membeli buku matematika dan bahasa Indonesia. Tahun 
berikutnya membeli buku dengan judul yang lain. Jumlahnya pun terbatas, tidak semua siswa dapat meminjam buku tersebut. Siswa yang tidak kebagian buku, akhirnya harus mengkopi dari buku siswa lain atau membelinya. Pada akhir tahun ajaran, buku tersebut harus dikembalikan lagi ke sekolah. Masalah yang muncul selain kurangnya jumlah dan jenis buku adalah buku tersebut tidak bisa diperoleh di awal tahun ajaran. Ini sangat tergantung dari pencairan anggaran. Dengan kondisi seperti ini, akhirnya muncul situasi pada awal tahun ajaran, siswa tetap harus membeli buku karena proses belajar mengajar tidak boleh ditunda karena ketiadaaan buku.

Selain itu, masalah yang lainnya adalah saat pengembalian buku di akhir tahun ajaran. Buku yang dikembalikan juga sebagian tidak dapat digunakan lagi karena hilang atau rusak. Untuk yang rusak, orangtua harus mengembalikan dengan buku yang sama, sedangkan untuk yang rusak, tidak ada sanksi apapun. Pada akhirnya, buku ini tidak dapat digunakan lagi untuk masa tahun ajaran berikutnya.

Masalah terakhir adalah Permendiknas tentang Buku dianggap kebijakan yang elitis. Kebijakan ini didefinisikan bebas sebagai kebijakan yang hanya mementingkan kelompok tertentu. Jadi hanya melihat kebutuhan sekelompok orang-orang yang sudah memiliki akses lebih, padahal kan halhal seperti ini dirancangnya untuk memenuhi kebutuhun terbesar mayoritas rakyat Indonesia yang ada di pedesaan.

\section{Simpulan dan Saran}

Hasil penelitian menunjukkan bahwa Permendiknas Nomor 2 Tahun 2008 sudah dilaksanakan, namun demikian belum berjalan dengan baik di semua pemangku kepentingan. Masalah-masalah yang dihadapi dalam pelaksanaan Permendiknas ini adalah minimnya sosialisasi tentang Buku Sekolah Elektronik (BSE), tidak memadainya infrastruktur teknologi informasi yang dibutuhkan untuk mengakses BSE, ketidaksesuaian materi BSE dengan kurikulum yang berlaku, ada indikasi kerjasama guru/sekolah dengan penerbit dalam menjual buku cetak, tidak meratanya distribusi buku pelajaran, rendahnya kualitas cetakan BSE, Permendiknas tentang Buku 
dianggap mematikan iklim persaingan usaha, kualitas sumber daya manusia pendidik dan siswa yang belum merata, terlambatnya distribusi BSE yang telah dicetak oleh pemerintah akibat keterlambatan pencairan anggaran, dan Permendiknas tentang Buku dianggap sebagai kebijakan yang elitis.

Dengan munculnya masalah-masalah yang cukup mendasar ini, ada baiknya pemerintah dalam membuat kebijakan yang akan diberlakukan secara nasional harus juga mempertimbangkan kondisi nasional tanpa menghilangkan latar belakang dan karakteristik masyarakat yang ada. Sosialisasi program secara terpadu dapat membantu berjalannya sebuah program secara efektif dan efisien. Berbagai media dan jaringan dapat dipergunakan untuk mendapat hasil maksimal dalam proses sosialisasi. Bagi pihak swasta disarankan untuk tidak hanya berpikir profit semata, tanggung jawab membangun bangsa dengan mencerdaskan masyarakat merupakan cita-cita bersama yang harus ditopang oleh semua pihak. Kepentingan sesaat yang terbangun dalam proses penyampaian buku (bahan ajar) tidak seharusnya mengorbankan pihak lain dalam hal ini masyarakat (murid dan wali murid). Bagi guru, sebagai aktor sentral dalam kegiatan belajar mengajar, bukan saatnya lagi menjadi pihak yang hanya menerima buku apalagi terlibat dalam rent seeking. Sudah saatnya bagi guru untuk berpikir proaktif dan kreatif dalam mengembangkan kegiatan pengajaran dengan melakukan pengayaan keilmuan melalui berbagai sumber. Bagi masyarakat (murid/wali murid dan komite sekolah) yang selama ini seringkali merasa menjadi korban kebijakan, sebaiknya dapat melakukan fungsi kontrol secara lebih baik dan berkesinambungan dalam kegiatan belajar mengajar yang berlangsung.

\section{Daftar Pustaka}

Ann, Crabbé and Leroy, Pieter. 2008. The Handbook of Environmental Policy Evaluation, London and Sterling, VA: Earthscan.

Chambliss, Marilyn J and Calfee, Robert C. 1998.. Texbook for Learning: Nurturing Children's Minds, Wiley-Blackwell. 
Jurnal Penelitian dan Evaluasi Pendidikan

Lester, J. P and Stewart, J, JR. 2000, Public Policy: An Evolutionary Approach, 2nd edition. Wadsworth, Belmont.

Loveridge, AJ 1972, terj. Hasan Amin, Persiapan Naskah Buku Peladjaran Pembimbing bagi Pengarangn di Negara-Negara Berkembang, Balai Pustaka.

O'Toole, L.J, 2000. "Research on Policy Implementation," Assessment and Prospects. Journal of Public Administration Research and Theory, 10(2).

Republik Indonesia, Peraturan Menteri Pendidikan Nasional Nomor 11 Tabun 2005 tentang Buku Teks Pelajaran.

$\longrightarrow$ Peraturan Menteri Pendidikan Nasional Nomor 2 Tabun 2008 tentang Buku.

, Undang-Undang Nomor 20 Tabun 2003 tentang Sistem Pendidikan Nasional, Lembaran Negara Tahun 2003 Nomor 78.

www.maroskab.go.id

324 - Jurnal Penelitian dan Evaluasi Pendidikan Tahun 16, Nomor 1, 2012 